\title{
CIWIDEY VALLEY RESORT TOURISM OBJECT DEVELOPMENT AS DETERMINANT OF INCREASING TOURIST VISITS
}

\author{
Supriatna $^{1}$, Haryono Sudriamunawar ${ }^{2}$, Waluyo Zulfikar $^{3}$ \\ Administrasi Bisnis, FISIP Universitas Nurtanio \\ yana.orbit@gmail.com ${ }^{1}$,izoel007@gmail.com ${ }^{2}$
}

\begin{abstract}
Ciwidey Valley Resort which is Tirta Tourism located in Ciwidey Tourism Area Precisely on KM.17 Road Barununggal Rancabali Bandung Regency, West Java is an artificial Tourism Area built in 2015 provides complete facilities for tourists who want to visit tourist locations including water warm water park, play ground, unique lodging, camping ground and ciwidey valley restaurant. The aim of this research is to find out how to develop Ciwidey Valley attractions in an effort to increase tourist arrivals that have an impact on Ciwidey Valley managers' income and regional budget revenues.The methods used by researchers in this study include descriptive analysis with a qualitative approach. Researchers use the development model according to Syamsu (2011) While the data collection techniques that the authors use in this study are the study of literature / documentation, observation, and interviews. Whereas the data validity technique uses triangulation.The initial step taken is to analyze the internal and external environment to find out how the service efforts provided in carrying out services and processes in carrying out tasks in the implementation of work processes. After that researchers also analyzed by interviewing with informants who have been determined previously to find out how the service and how the process of service provided by all workers in Ciwidey Valley Resort to visitorsThis research can be concluded by the researchers, that in an effort to increase the number of tourist arrivals by developing several tourist attractions supported by improving services but not all are optimal.
\end{abstract}

\section{Keywords: development, tourists}

\section{Introduction}

Background

Bandug Regency is an area that has a lot of tourist attractions, in almost every region in the Bandung regency there are tourist attractions, both natural and man-made tours, especially for the south Bandung area, namely the Ciwidey and Rancabali areas, many natural attractions which is expected to help raise the founding of the Regional Budget generally can increase the deposition of communities around the area in the area, the area of southern Bandung to be shady, green and beautiful. The area that has natural beauty that is very abundant, namely the area of southern Bandung which has agro activities has several tourist attractions managed by SOEs or private parties, including Cimanggu tourism, Kawah Putih, Situ Pateggang, Cimanggu hot spring, Ciwidey Valley.

\section{Resort}

When the author observed the Ciwidey Valley Resort Tourism Area to conduct research, the writer interviewed one of the employees who worked in the tourist area, which tells of the development program for several tourist areas in the Ciwidey Valley Resort tourist area that has been conducted every year, but still of course visitors did not experience a very significant increase, it was because of the location that was very far from the downtown crowd, even the manager had made efforts to increase visits through the marketing field who had tried to work with several aggregator sites that sell travel services for booking lodging tickets and tour package seller services in several regions in Indonesia.

The management has also cooperated with several tourism activists in Bandung Regency including the Indonesian Tour Guide Association (HPI) of the Bandung Regency Branch, the Hotel and Restaurant Association of Indonesia (PHRI) of the Bandung Regency branch, the Youth Tourism Drivers (PAPRIKA) of Bandung Regency in an effort to promote tourism in the Regency Bandung in particular Ciwidey Valley Resort Tourism with the aim of increasing tourist arrivals, so that it can have an impact on manager's income. Based on the survey data conducted 
by researchers, it can be seen that the Ciwidey Valley Resort Tourism Area will not experience significant development and it can be said that it will continue to run static if management stays like this with the price of tickets and rides at Ciwidey Valley Resort as explained above. . This has a negative impact on income in Ciwidey Valley Resort in Bandung Regency.

One of the factors that can help provide solutions to increase manager income is to make Ciwidey Valley Resort Tourism area a leading destination in Bandung Regency with efforts to improve and develop several public facilities that are not only focused on increased accommodation but can be helped by optimizing promotions through advertising, electronic media and online media. This study aims to make the Ciwidey Valley Resort area a leading tourist attraction in Bandung Regency, Bandung Regency so that it can increase visits that have an impact on the income of managers and communities around Ciwidey Valley Resort and increase State Foreign Exchange earnings in the Tourism sector.

Tourism is a growing industry with many tourist attractions and tourist support facilities such as hotels, places eating along the way to tourism and many travel agencies that provide travel agent services that are expected to have an impact on the economic, social and cultural life of the nation such as, one of which can provide employment opportunities for human resources who have skills in tourism and state income from the sector tax and foreign exchange are increasing. It can be seen that there are many problems in some tourist areas, namely the lack of awareness of the tourism marketing that is carried out by the management and tourism management which is still not good so that the impact on the decline in tourist visits. The manager must be able to manage it well again so that the tour can develop.

As said by Syamsu, et al (2011: 8) that planning the development of a tourist area requires several stages in its development efforts, among others: Market Aspects, Marketung Aspects, Production Aspects, Aspects of Human Resource Sumbe, empowering human resources in the environment around tourism and parties parties and several advertising agencies to further promote the tour must pay attention to several factors including factors: (1) Scarcity factors, namely: tourist attractions that cannot be found in other tourist attractions in other words the tourist attractions must have a keuinak or has tourist attractions that are very advanced compared to other tours around the tour. The scarcity can be either artificial or artificial tourism. (2) Naturalism factor, namely: tourist attraction that is still truly original and has not been changed by human behavior or natural changes that can damage the natural beauty before, the tourist attraction can be in the form of culture and very beautiful natural attractions that have not experienced much change by human behavior. (3) Uniqueness Factor (Uniqueness) is a tourist site that has its own characteristics compared to other tours, among others, from the tourist attractions that can be enjoyed by. (4) Community empowerment factors. Public awareness of the existence of tourism in the environment to maintain and help promote the tour so that it has a real impact on the progress of the tour and of course there must be embracing from the manager to maintain public awareness so as to feel each other has a tour that is around the community so as to cause hospitality tourist for visitors who travel to the tourist area. (5) Land Optimization Factor (Area Optimalsation) which means that the land is used as a nature tourism area which is used according to several optimization considerations in accordance with the target mechanism.

Without forgetting conservation, preservation and protection considerations. (6) To create unity and the more integrated between the community and the manager, the equalization factor must be regulated in such a way so that it can generate enormous benefits to the tourist areas and communities involved in it.

Ciwidey Valley Resort Tourism Manager Rancabali Bandung Regency is fully responsible for the implementation of the tourism promotion strategy which is fully surrendered to the Marketing field, so that the implementation of the tourism promotion strategy in the Ciwidey Valley Resort tourism area can be carried out well in increasing the number of tourist visits, the things that need to be done are by adding several tourist facilities and then assisted with better promotion and building good cooperation with various parties to support the implementation of tourism promotion 
strategies in Ciwidey Valley Resort Tourism District Bandung District.

\section{Method}

According to Bogdan and Taylor in Moleong (2016: 4) defines a qualitative methodology as a research procedure that produces descriptive data in the form of written or oral words from people and observable behavior. According to them, this approach is directed towards the background and individuals holistically. In line with this definition, Krik and Miller in Moleong (2016: 4) define that qualitative research is a particular tradition in social science that is fundamentally dependent on human observations both in their area and in their territories. In qualitative research, researchers themselves or with the help of others are the main data collection tools. This was done because if using non-human tools and preparing themselves in advance as commonly used in classical research, it would be impossible to make adjustments to the realities in the field (Moleong, 2016: 9). Data collected in qualitative research are in the form of words, images, and not numbers that are commonly referred to as descriptive. Thus according to Moleong (2016: 11) the research report will contain data excerpts to provide an overview of the presentation of the report. The data may come from interview scripts, field notes, photos, videotapes, personal documents, notes or memos, and other official documents.

In accordance with the phenomena reflected in the research objectives, the approach used is a qualitative approach with descriptive analysis methods. The data obtained in this study is about the chronology of the dynamics of the Bandung regency tourism area, especially the Ciwidey Valley Resort Tourism, including the legal instruments that protect them, Data Sources and Types Included in the main informants or key informants in this study are those who have experience or intensity involved in the development of tourism in the Bandung District region and in particular those who develop the Ciwidey Valley Resort tourist area.

Those who have very influential positions in their positions can be used as key informants in this study so that they can provide very accurate data needed by researchers. Triangulation can be done by researchers so that there is no bias in research conducted by researchers, triangulation can be done by comparing data and information obtained to be tested for validity, it requires very precise key informants who have important positions in a company that is a research researcher so that it can provide the documents needed to support data (primary), and supporting data (secondary), such as monthly reports, annual visitor data, relevant previous research that can be used as references in compiling researchers' scientific work that can be obtained through journals or books previous thesis books, books, statistical data or other relevant sources.

Key informants are determined according to the needs of research data, namely those who are considered to be very potential to be key informants, because they have comprehensive and adequate knowledge about tourism development or Bandung Regency tourism development strategies especially Ciwidey Valley Resort tourism to become national tourism, as key informants. The basis for this election is that they are representatives of each party that is directly related to the issues examined in this study. People who really understand the development of a tourist area so that they can solve a problem that exists in the tourist area of Bandung district, especially the Ciwidey Valley Resort tourist area

Table 1

List of Informan Criteria

\begin{tabular}{lll}
\hline \hline No & Informan Criteria & Informan \\
\hline 1 & Bandung Regency Tourism & $\begin{array}{l}\text { Head of Bandung Tourism and } \\
\text { Culture Office }\end{array}$ \\
\hline 2 & Mapping Bandung Regency Tourism & $\begin{array}{l}\text { Head of Bandung Regency } \\
\text { Tourism Destination Division }\end{array}$ \\
\hline 3 & Driver of Ciwidey Valley Resort & $\begin{array}{l}\text { Chief Manager of Ciwidey Valley } \\
\text { Resort }\end{array}$ \\
\hline \hline
\end{tabular}




\begin{tabular}{lll}
\hline No & Informan Criteria & Informan \\
\hline 4 & Tourists in Ciwidey Valley Resort & $\begin{array}{l}\text { Leader Rekreasi, Food \& Resto, } \\
\text { Medical Engineering, } \\
\text { Housekeeping Hotel dan Leader } \\
\text { Marketing }\end{array}$ \\
\hline 5 & Tourist Visitors & Local and National tourists \\
\hline \hline
\end{tabular}

Sumber : Writer, 2019

\section{Result and Discussion}

Ciwidey Valley Resort Bandung Regency Tourism Development Program is a program created by managers to increase tourist visits. With the existence of a sustainable development program, it is hoped that it can attract the interest of local and foreign tourists to come to Ciwidey Valley Resort tourist destination.

Furthermore, researchers describe the results of research that has been done through observation, interviews and literature / documentation studies on the Development of Ciwidey Valley Resort Tourism Objects as a Determinant of Increasing Tourist Visits using the theory of Syamsu, et al (2011) that planning the development of a tourist area requires several stages in its development efforts among others: Market Aspects, Marketung Aspects, Production Aspects, Human Resources Sumbe Aspects, empowering human resources in the environment around tourism and parties and several advertising agencies to further promote these tourisms must pay attention to several factors including factors: (1) Factors of scarcity (Scarcity), namely: tourist attractions that can not be obtained at other tourist attractions in other words, the tourist attractions must have a keuinak or have tourist attractions that are very superior compared to other tours that are around the tour.

The scarcity can be either artificial or artificial tourism. (2) Naturalism factor, namely: tourist attraction that is still truly original and has not been changed by human behavior or natural changes that can damage the natural beauty before, the tourist attraction can be in the form of culture and very beautiful natural attractions that have not experienced much change by human behavior. (3) The uniqueness factor, namely: the character of the object / attraction of a tourist that has a comparative advantage compared to the ecotourism that is right around the tour. (4) Community empowerment factors. Public awareness of the existence of tourism in the environment to maintain and help promote the tour so that it has a real impact on the progress of the tour and of course there must be embracing from the manager to maintain public awareness so as to feel each other has a tour that is around the community so as to cause hospitality tourist for visitors who travel to the tourist area. (5) Land Optimization Factor (Area optimization) means that the area used as a nature tourism area is used according to optimization considerations in accordance with market rules. Without eliminating some of the considerations of conservation, preservation, and protection. (6) To create unity and the more integrated between the community and the manager, the equalization factor must be regulated in such a way so as to produce a very large benefit to the tourist area and the community involved in it.

Ciwidey Valley Resort is one of the subsidiary companies engaged in the tourism industry Ciwidey Valley Resort was founded in 2005. The company is located at Jl. Raya Barutunggul Ciwidey-Rancabali KM 17 Containing Regency with a building area of approximately $300 \mathrm{~m} 2$. Ciwidey Valley Resort in accordance with the vision and mission created which is a reference Ciwidey Valley Resort in the implementation of differentiation includes various aspects found in the study as follows: 1) aspects of the market are aspects that provide a picture of profits for Ciwidey Valley Resort. By considering the market aspect, one of the potential tourism markets can be seen in absorbing the products being sold. If the market's ability to absorb products is high enough with an effective selling price, it will be able to provide benefits to Ciwidey Valley Resort. This aspect is highly studied by the Manager of Ciwidey Valley Resort so that the products produced can meet the needs and satisfaction of local and foreign tourists. 
Market aspects consist of several factors, including among others.

\section{a) Market Segments}

The market is one comprehensive process where the company must pay attention to the purchase of each segment, at least the business will be more economical if the purchase units are grouped into several groups. All of this is inseparable from efforts to achieve maximum profit. The division of markets in a market group is strongly influenced by the type of product, the character of demand, one way to channel, the media available for marketing communication and consumer purchasing motivation. The importance in determining the target market requires market segmentation on the basis of appropriate and useful segmentation for marketing development planning

\section{1) Target Market}

Ciwidey Vallley Resort in determining the target market must see whether a potential segment has generally attractive characteristics such as size, growth, profitability, economies of scale, low risk.

\section{2) Positioning}

Positioning is an image or image formed in a tourist's memory from a tourist name. Posititioning, among others, how a tour according to the views of tourists that distinguishes it from other tours. Means of tourism are the completeness of the tourist destination areas needed to meet the needs of a tourist in enjoying his tour

\section{Marketing Aspects}

Marketing aspect as a marketing reference, which sets the best composition of several marketing components, in order to achieve the target market, and at the same time achieve the company's goals and objectives. The Market Aspect itself consists of several supporting aspects including:

\section{a) Product}

Pure product in tourism is in the form of memories generated by tourists during a tour in the Ciwidey Vallley Resort tourist area where the product will be fulfilled if there are many rides that can satisfy tourists.

\section{b) Price}

The price is the amount of money charged for a Ciwidey Valley Resort tourism product, or the amount of value that consumers must pay to get the benefits of the product. The price serves as a measure of the value of a tourist, how to distinguish a tourist, determine the amount of goods to be produced and its distribution to tourists c) Promotion

Promotion in the intended development effort is a persuasive effort (persuasion or encouragement) to invite prospective tourists to come or tourists who have come to come back to the Ciwidey Valley Resort tourist area so that it can increase the income of the manager of the tourist area

\section{d)Placemet}

how to distribute tourism products so that they reach potential tourists according to the segmentation applied by the manager of the Ciwidey Valley Resort tourist area in Bandung Regency. The system varies depending on the policies made by each boss. At Ciwidey Valley Resort, there are not many methods used to promote the Ciwidey Valley Resort tourist area

\section{Human Resources}

Human Resources greatly influences whether or not the tourist area is advanced. It is undeniable that these factors play an important role in making progress or even a setback from a tourist area. And this is one of the factors where tourism managers really want to have superior Human Resources. Ciwidey Valley Resort Bandung Regency receives a person to work on Ciwidey Valley Resort Tourism by using some resistance. But there are still things that cannot be done unilaterally is the accepting of the origin of the employees themselves who are required from the local population because it has already established cooperation with the local government namely the village of Alamendah Process The Standard Operating Procedure (SOP) itself to explain the details or fixed standards regarding repetitive work activities organized by Wana Wisata Ciwidey Valley Resort. As explained by several informants that in Ciwidey Valley Resort Tourism area workers are required to work as professionally as possible with the Standard Operating Procedures that have been set previously, in order to show a very good process in the eyes of tourists c) Physical Evidence / Physical Evidence Ciwidey Valley Resort seeks to add tourist attractions by sharing innovations owned by various fields, and maintenance of facilities 
and infrastructure of the tourist area is carried out to guarantee the facilities and infrastructure available in Ciwidey Valley Resort tourist area in good condition and ready for tourists to use. The purpose of maintenance itself can have an impact on the longevity of the use of facilities and infrastructure used in business processes, Avoiding fatal damage to some of the rides at Ciwidey Valley Resort, resulting in long repair times and large repair costs.

\section{1) Production Aspects}

A good production system must be able to produce tourist products as desired by tourists. In general, a system that is measured based on the ability to make on a large scale and has a quality that is determined based on the wishes of tourists, the ability of company resources and the expectations of managers as owners and perhaps as well as managers. in the production system there are 2 (two) components, namely input (facilities and infrastructure), and output output (perceived benefits)

\section{a) Means}

Means of tourism are the completeness of the tourist destination area needed to serve the needs of tourists in enjoying the tour. the manager tried to build facilities and infrastructure well to increase the number of visits, but in the second time returned to tourists who visit because each visitor has different tastes and views of the tourist area Ciwidey Valley Resort Bandung Regency. he output is utilized and also felt in this aspect of production secara langsung is to increase profits by producing goods or services that are done well can increase profits not only to the manager but also to the side of tourists who come to the tourist area Ciwidey Valley Resort. the benefits of Ciwidey Valley Resort tourism, in the implementation is the ease of the community in getting jobs, because it can be channeled directly by village officials to enter Ciwidey Valley Resort if there is a shortage of employees.

Human Resources is one of the factors that play an important role in advancing the tourism sector. The Importance of Human Resources in the tourism sector, namely people (people) is a very important resource in most groups. Especially in service-based groups (service-based organization), Human Resources

Tourism is all aspects of humanity that support tourism activities both tangible or intangible which aim to meet the needs and create the creation of tourist satisfaction and have a positive impact on the economy, welfare, and environmental and cultural preservation

\section{Conclusion}

Based on data analysis and discussion and findings it can be concluded as follows:

1.Conclusions

a. The market is a comprehensive process in which tourism managers must pay attention to visits from each segment, at least the development will be more effective and economical if the units of need itu grouped into just a few groups. However, in promoting the Ciwidey Valley Resort tourist area, the managers do not use the market segment theory, because basically anyone who is able can visit the Ciwidey Velley Resort tourist area, all of which are the main market segments of the managers. b. Ciwidey Vallley Resort in determining the target market must see whether a potential segment has generally attractive characteristics such as size, growth, profitability, economies of scale, low risk and others. in attracting visitors to come in general there are no specific targets for prospective tourists, there are indeed some facilities that are specialized for various activities and of course with special markets including the hall-halls commonly used for meetings and seminars

b. Positioning is the image that is formed in the mind of a tourist from a tourist name. Positioning is a different perspective in the minds of tourists with other tours. Ciwidey Valley Resort from year to year continues to strive and develop tourist areas in accordance with what is needed by potential tourists so that tourism products are expected to emerge that are really expected by tourists who come to the tourist area Ciwidey Valley Resort c. Products in marketing aspects are all forms offered to prospective tourists to be used or consumed so that they can meet the needs and desires of tourists. The desire of these tourists can be physical, services, in the implementation of the stakeholders involved in the management of the area always trying 
to provide the best service so that tourists who come have enjoyed the tourist products provided by the manager of the Ciwidey Valley Resort tourist area Bandung Regency d. Price is the amount of money charged to a service (goods or services), and the amount of value that must be paid by tourists in order to receive benefits from the tourist products he visits. Price acts as a measuring tool for a tourist area, how to distinguish an item, determine the amount of goods to be produced and its distribution to consumers. The price is important so that the Ciwidey Valley Resort tour can flourish and be visited by many tourists. but the managers collided with the amount of very expensive production boarding, so that the impact on the high ticket Ciwidey Valley Resort tourist visits Bandung Regency.

e. Promotion in the intended development effort is an effort to directly invite prospective tourists to come and tourists who have come to come back to the Ciwidey Valley Resort tourist area so that it can increase the income of the manager of the tourist area. promotion is important for developing Ciwidey Valley Resort tourist area. the managers have not been maximized in terms of promotion, it is because the managers are still focused on maximizing services in which so indirectly it has become part of the tourism promotion Ciwidey Valley Resort Bandung Regency

a. In an effort to deliver existing tourism products at Ciwidey Valley Resort in Bandung Regency, the Tourism and Culture Office of Bandung Regency through the Field of Destinations only provides recommendations for the advancement of a tourism industry in collaboration with various elements of tourism driving organizations in Bandung Regency. Among them are the Indonesian Tourism Association (HPI), the Tourism Driving Group (KOMPEPAR), the Indonesian Hotel and Restaurant Association (PHRI) and the Youth Tourism Movers (PAPRIKA), which have their respective main duties and functions expected to be able to convey tourism products produced by the tourism industry to prospective tourism. traveler. b. Ciwidey Valley Resort cannot accept Human Resources from outside the Rancabali District of Bandung Regency, in addition to the welfare of the people around, other purposes are also to be easily controlled if things happen that are not wanted, especially for the security sector and the cleaning service sector. the village forms its own outsourcing for the field which will be channeled in the Ciwidey Valley Resort tourist area, in the implementation the manager assigns every field leader to continue to monitor or train in advance the human resources working in the tourist area to work professionally in accordance with the field he is in. regarding the acceptance of Human Resources that must be employed in the Ciwidey Valley Resort tourist area, so there is a provision if those working in the Ciwidey Valley Resort tourist area must be people around who are in the Rancabali District of Bandung Regency in particular 3 (three) RWs in Alamendah Village, however in its implementation the manager dares to be the quality of the human resources employed in the tourist area, because before entering those who want to work in the cation the training is in accordance with the field they later place

b. Standard Operating Procedure (SOP) is a work guide that is used to achieve a goal set by the management leader and staff in the Ciwidey Valley Resort tourist area at the lowest possible cost. The purpose of making the Standard Operating Procedure (SOP) itself is to explain the details or fixed standards regarding the repetitive work system that is organized by the Ciwidey Valley Resort Tourism Area. Ciwidey Valley Resort Tourism workers are required to work as professionally as possible with a predetermined Standard Operating Procedure, in order to demonstrate a very good process in the eyes of tourists. c. Physical evidence in general is all in the form of equipment or devices used to support the running of the business, especially in the effort to plan the development of tourist areas in order to increase the number of visits. the manager continues to try to add tourist attractions by sharing innovations owned by various fields, and maintenance of tourism 
facilities and infrastructure is carried out to guarantee the facilities and infrastructure that exist in Ciwidey Valley Resort tourism area. d. The correct mode of production must be able to produce the tourist products desired by tourists, where a system is measured by the ability to make the number and quality determined based on the needs of tourists, the ability of Simber Human Resources Ciwidey Valley Resort and the expectations of entrepreneurs as owners and perhaps as well as managers. the production system is known to have 2 (two) components, namely input (facilities and infrastructure), and output output (perceived benefits) in this case the Ciwidey Valley Resort Tourism area is quite complete especially for lodging where there are 81 (eighty-one) rooms are divided into 33 (thirty-three) cottages, 10 (ten) Camper Rooms, 4 (four) Room Countainer), 8 (eight) Sahara Glamping, and 36 (thirty-six) Hottels. In terms of attractions in the Ciwidey Valley Resort tourist area there are several attractions that can be enjoyed by visitors, including 2 (two) swimming pools with one hot water for adults with a depth of

\section{References}

A. Book Resource

Middleton, VTC, 1994 Marketing in Travel and Tourism Second Edition. UK: Butterworth, Heineman Ltd

Miles, Matthew B. \& A. Michael Huberman,

2009 Analisis Data Kualitatif, UI-Press, Jakarta

Moleong, Lexy J, 2016 Metodologi Penelitian Kualitatif, Remaja Rosdakarya, Bandung

Siagian, 2004 Manajemen Sumber Daya Manusia, Jakarta : Bumi Aksara

Siagian, silalahi. 2013 Studi Tentang Ilmu Administrasi, Sinar Baru Algesindo, Bandung.

Soewrno. 2002 Pengantar Studi Ilmu Administrasi dan Manajemen, Jakarta : Gunung Agung.

Som, Ahmad Puad Mat and Mohammad Bader Badarneh.

2011 Tourost Satisfaction and Repeat Visitation; Toward a New Comprehensive Model, International Journal of Human and Social Sciences approximately 2 (two) meters and a cold water pool for young children, As for selfi rides that can be used for people who like photos, at Ciwidey Valley Resort there are many photo spots that can be used as object objecks including birdwatching. But of the many facilities and infrastructure available at Ciwidey Valley Resort

a. less giving benefits to the surrounding community which is seen from a social perspective less accepting of the overall impact as well as the economy has not been too impactful because of the lack of visitors who come to Ciwidey Valley Resort tourism.

b. Human Resources is one of the factors that play an important role in advancing the tourism sector. Ciwidey Valley Resort has Human Resources with an average age of 20 to 30 years, while for the level of education the majority of high school / equivalent, but that does not reduce their enthusiasm for work and they tend to be easy to train. They work with the Shif system with an average of 8 hours / day.

Spillane, James. 1993 Ekonomi Pariwisata, Sejarah dan Prospeknya. Yogyakarta: Kanisius

Sudriamunawar. Haryono 2010 Pengantar Studi Administrasi Pembangunan. Mandar Maju . Bandung

Syamsu, dkk. 2011 Penerapan Etika Perencanaan Pada Kawasan Wisata, study kasus di kawasan argo wisata salah pondok, Kabupaten Sleman, Daerah Istimewa Yogyakarta. Jakarta : LPM STP Tri Sakti, Jurnal Ilmiah Vol 5. No 3 Maret 2001

Wahab, S. and C. Cooper 2001 Tourism in the Age of Globalisation . London: Rautletge

C. Journal Reference

Desnanto, Rio Nur, "Analisis Potensi Wisata Alam Untuk Pengembangan Wisata Di Kabupaten Karanganyar 2013, Program Studi Sosiologi, Fakultas Ilmu Sosial Dan Politik, Universitas Sebelas Maret Surakarta Jawa Tengah

Rani, Maha, Prasetya, Deddy , Julham, Pengembangan Potensi Pariwisata 
Kabupaten Sumenep, Madura, Jawa Timur (Studi Kasus: Pantai Lombang, 2013, Program Studi Ilmu Politik, Fakultas Ilmu Sosial Dan Ilmu Politik, Universitas Airlangga Surabaya Jawa Tengah
Sugandi, Dede dan Supriatin, Titing Supriatin Pengembangan Objek Wisata Pantai Santolo Di Kawasan Wisata Pameungpeuk Garut Selatan.

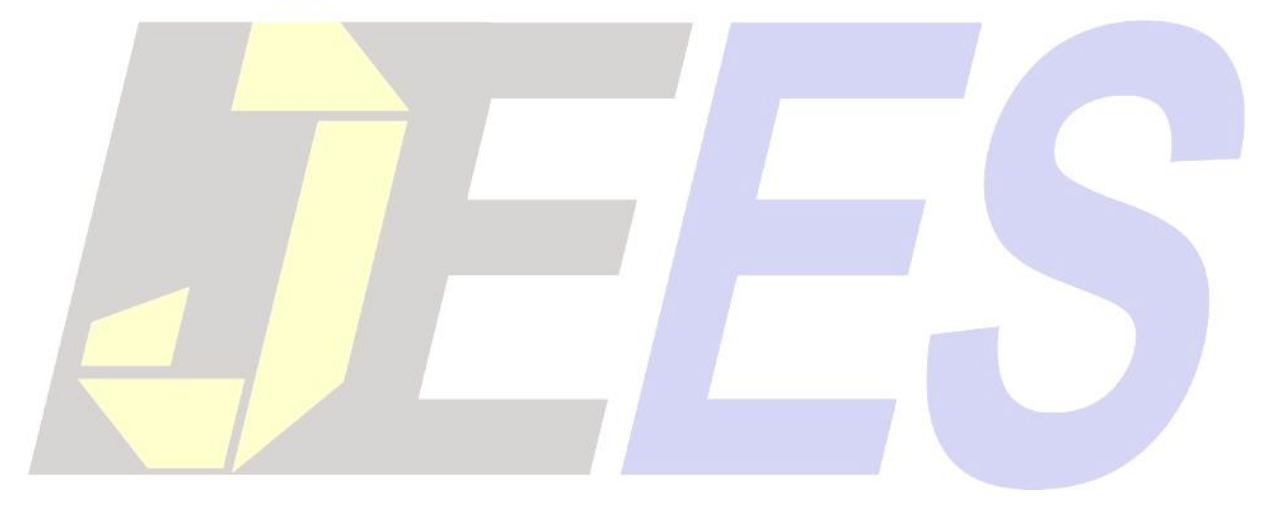

